\title{
Gambaran USG pada Pasien Nodul Tiroid di Bagian/SMF Radiologi FK Unsrat RSUP Prof Dr. R. D. Kandou Manado Periode Juni 2016 - Mei 2017
}

\author{
${ }^{1}$ Yonathan \\ ${ }^{2}$ Vonny N. Tubagus \\ ${ }^{2}$ Ramli Haji Ali
${ }^{1}$ Program Studi Pendidikan Dokter Fakultas Kedokteran Universitas Sam Ratulangi Manado
${ }^{2}$ Bagian Radiologi Fakultas Kedokteran Universitas Sam Ratulangi Manado
Email: yonathanzhang3@gmail.com

\begin{abstract}
Thyroid nodule is commonly found and can be caused by various types of disorders of the thyroid gland. In Indonesia, the statistics of thyroid disorders is still lacking. Ultrasonography (USG) is the standard modality in radiological diagnosis and evaluation of thyroid nodule. This study was aimed to determine the USG results of patients with thyroid nodules at Radiology Department of Prof. Dr. R. D. Kandou Hospital, Manado. This was a retrospective descriptive study. Data were obtained from neck USG request forms. There were 102 patients with radiological diagnosis of thyroid nodules out of 241 patients $(42.3 \%)$ with neck USG, consisted of 79 females $(77.5 \%)$ and 23 males $(22.5 \%)$. The most common age groups were 40-49 years and 50-59 years, each of 28 patients (27.5\%). Benign thyroid nodules were found in 88 patients $(86.3 \%)$. The most common USG imaging was eggshell calcification found in 45 patients $(44.1 \%)$. Conclusion: The majority of patients with thyroid nodules were females, age groups of 40-49 years and 50-59 years, had benign type nodules, and USG imaging as eggshell calcification.
\end{abstract}

Keywords: thyroid nodules, ultrasonography

\begin{abstract}
Abstrak: Nodul tiroid merupakan kasus yang sering ditemukan dan dapat disebabkan oleh berbagai jenis gangguan pada kelenjar tiroid. Di Indonesia, data statistik nodul tiroid masih sangat kurang. Pemeriksaan ultrasonografi (USG) merupakan modalitas radiologik standar dalam mendiagnosis dan mengevaluasi nodul tiroid. Penelitian ini bertujuan untuk mengetahui gambaran USG pada pasien dengan nodul tiroid di Bagian Radiologi RSUP Prof. Dr. R. D. Kandou Manado. Jenis penelitian ialah deskriptif retrospektif menggunakan data sekunder yang diperoleh dari rekam medik lembaran permintaan pemeriksaan USG leher. Hasil penelitian mendapatkan 102 dari 241 pasien yang dilakukan USG leher $(42,3 \%)$ dengan diagnosis radiologik nodul tiroid. Terdapat 79 pasien perempuan $(77,5 \%)$ dan 23 pasien lakilaki (22,5\%). Kelompok usia tersering ialah 40-49 tahun dan 50-59 tahun, masing-masing 28 pasien $(27,5 \%)$, Nodul tiroid paling banyak bersifat jinak (benigna) berjumlah 88 pasien (86,3\%), dan gambaran USG nodul tiroid paling banyak ditemukan eggshell calcification pada 45 pasien $(44,1 \%)$. Simpulan: Mayoritas pasien dengan diagnosis radiologik nodul tiroid berjenis kelamin perempuan, kelompok usia 40-49 tahun dan 50-59 tahun, nodul bersifat jenis dengan gambaran eggshell calcification.
\end{abstract}

Kata kunci: nodul tiroid, ultrasonografi

Tiroid merupakan salah satu kelenjar endokrin berbentuk seperti kupu-kupu yang terletak di leher bagian bawah. Fungsi utama tiroid ialah menghasilkan hormon tiroksin (T4) yang kemudian diubah menjadi bentuk aktifnya yaitu triyodotironin 
(T3) yang disekresi ke dalam darah dan kemudian dibawa ke jaringan tubuh lainnya. ${ }^{1}$

Nodul tiroid adalah pembesaran yang teraba pada kelenjar tiroid di daerah leher. Nodul tiroid merupakan suatu pertumbuhan sederhana yang cepat dari jaringan tiroid normal, kista berisi cairan, inflamasi (tiroiditis), atau tumor (jinak atau ganas). Nodul tiroid diindikasikan dengan adanya satu atau beberapa nodul yang berada di dalam kelenjar tiroid. ${ }^{2,3}$ Nodul tiroid merupakan kasus yang sering ditemukan dan dapat disebabkan oleh berbagai jenis gangguan pada kelenjar tiroid. Meskipun kebanyakan nodul jinak, tetapi sekitar 5\% dari nodul yang teraba ialah nodul ganas. ${ }^{3}$

Di Amerika Serikat dengan jumlah penduduk lebih dari 275 juta, diperkirakan sekitar 20 juta orang mengalami berbagai kelainan tiroid. Di Pakistan, 8 juta orang penduduk mengalami kelainan tiroid akibat kekurangan yodium. ${ }^{4}$ Di Indonesia, data statistik nodul tiroid masih sangat kurang. Diperkirakan terjadi peningkatan prevalensi total goitre rate dari $9,8 \%$ pada tahun 1998 menjadi $11,1 \%$ pada tahun 2003. Prevalensi kelainan tiroid dipengaruhi oleh jenis kelamin dan usia. Kelainan tiroid pada perempuan terjadi 4-10 kali lebih sering dibandingkan dengan laki-laki. ${ }^{5}$

Nodul tiroid umumnya dapat dideteksi dengan menggunakan ultrasonografi(USG) sampai $60 \%$ dari seluruh populasi. Data dari the Surveillance Epidemiology and End Results (SEER) memperlihatkan adanya peningkatan prevalensi diferensiasi kanker tiroid diseluruh dunia dengan jumlah terbanyak yang terdeteksi ialah small pappilary carcinoma. ${ }^{2}$ Sebagai evaluasi awal pada pasien dengan nodul tiroid dilakukan fine needle aspiration (FNA) yang memberikan hasil diagnostik cepat, murah, dan aman. ${ }^{6}$ Peningkatan diagnosis prevalensi karsinoma tiroid dengan ultrasonografi (USG) juga meningkatkan prosedur diagnostik sitologi. Ultrasonografi tiroid merupakan modalitas utama dalam mengevaluasi nodul tiroid. Dengan menggunakan USG, nodul tiroid tampak sebagai lesi noduler di dalam kelenjar tiroid yang dapat dibedakan dengan parenkim sekitarnya.,

Penelitian ini bertujuan untuk mendapatkan gambaran nodul tiroid menggunakan modalitas USG dari data rekam medik pasien dengan nodul tiroid di Bagian Radiologi FK Unsrat/ SMF RSUP Prof. Dr. R. D. Kandou Manado selama periode Juni 2016 - Mei 2017.

\section{METODE PENELITIAN}

Jenis penelitian ialah deskriptif retrospektif. Penelitian dilakukan di Bagian/ SMF Radiologi FK Unsrat RSUP Prof. Dr. R. D. Kandou Manado menggunakan data sekunder berupa rekam medis lembar permintaan USG tiroid dari pasien dengan nodul tiroid periode Juni 2016-Mei 2017. Untuk pengolahan data dilakukan secara manual menggunakan komputer.

\section{HASIL PENELTIAN}

Pada penelitian ini didapatkan 241 lembar permintaan pemeriksaan USG leher pasien dengan klinis yang mengarah pada nodul tiroid. Hasil ekspertise dari 241 lembar permintaan USG leher mendapatkan 102 pasien yang didiagnosis nodul tiroid (Tabel 1).

Tabel 1. Distribusi pasien USG leher berdasarkan diagnosis radiologik

\begin{tabular}{ccc}
\hline Diagnosis & n & \% \\
\hline Nodul tiroid & 102 & 42,3 \\
Diagnosis lain & 127 & 52,7 \\
Tidak ada kelainan & 12 & 5 \\
Total & 241 & 100 \\
\hline
\end{tabular}

Dari hasil penelitian didapatkan bahwa nodul tiroid paling banyak ditemukan pada perempuan berjumlah 79 pasien $(77,5 \%)$ sedangkan pada laki-laki berjumlah 23 pasien $(22,5 \%)$ (Tabel 2).

Tabel 2. Distribusi pasien nodul tiroid berdasarkan jenis kelamin

\begin{tabular}{ccc}
\hline Jenis kelamin & N & \% \\
\hline Laki-laki & 23 & 22,5 \\
Perempuan & 79 & 77,5 \\
Total & 102 & 100 \\
\hline
\end{tabular}


Dari hasil penelitian didapatkan bahwa nodul tiroid paling banyak bersifat jinak (benigna) yaitu berjumlah 88 pasien (86,3\%) sedangkan yang ganas (maligna) berjumlah 14 pasien $(13,7 \%)$ (Tabel 3).

Tabel 3. Distribusi pasien nodul tiroid jinak dan ganas

\begin{tabular}{cc}
\hline Sifat nodul tiroid & $\mathbf{\%}$ \\
\hline Benigna & 86,3 \\
Maligna & 13,7 \\
Total & 100 \\
\hline
\end{tabular}

Dari hasil penelitian didapatkan bahwa gambaran USG nodul tiroid paling banyak berupa eggshell calcification $(44,1 \%)$, diikuti oleh hyper-echoic $(9,8 \%)$ dan hypoechoic (4\%).

Dari hasil penelitian didapatkan bahwa pasien yang termuda berusia 21 tahun dan yang tertua berusia 81 tahun. Kasus nodul tiroid terbanyak didapatkan pada kelompok usia 40-49 tahun (27,5\%) dan kelompok usia 50-59 tahun $(27,5 \%)$, diikuti kelompok usia 30-39 tahun $(15,6 \%)$, dan kelompok usia 80-90 tahun (1\%) (Tabel 5).

Tabel 4. Distribusi pasien nodul tiroid berdasarkan gambaran USG

\begin{tabular}{ccc}
\hline Gambaran USG & N & \% \\
\hline Kalsifikasi perifer & 43 & 42,1 \\
Eggshell Ccalcification & 45 & 44,1 \\
Hyper-echoic & 10 & 9,8 \\
Hypo-echoic & 4 & 4 \\
Total & 102 & 100 \\
\hline
\end{tabular}

Tabel 5. Distribusi pasien nodul tiroid berdasarkan kelompok usia

\begin{tabular}{ccc}
\hline Kelompok usia & n & \% \\
\hline $20-29$ & 12 & 11,7 \\
$30-39$ & 16 & 15,6 \\
$40-49$ & 28 & 27,5 \\
$50-59$ & 28 & 27,5 \\
$60-69$ & 11 & 10,8 \\
$70-79$ & 6 & 5,9 \\
$80-90$ & 1 & 1 \\
Total & 102 & 100 \\
\hline
\end{tabular}

\section{BAHASAN}

Berdasarkan hasil ekspertise dari 241 lembar permintaan USG leher pada pasien didapatkan 102 pasien dengan diagnosis radiologik nodul tiroid. Hal ini menunjukkan bahwa nodul tiroid masih merupakan kasus yang cukup sering ditemukan di dunia medis. Ultrasonografi leher atau tiroid menjadi salah satu modalitas yang digunakan dalam mendiagnosis nodul tiroid. $^{4}$

Pasien nodul tiroid terbanyak didapatkan pada jenis kelamin perempuan (77,5\%) dibandingkan pada jenis kelamin laki-laki (22,5\%). Hasil penelitian ini sesuai dengan penelitian yang dilakukan oleh Pasaribu ${ }^{7}$ di RS H. Adam Malik tahun 2006 yang melaporkan bahwa data pasien terdiagnosis nodul tiroid berdasarkan hasil ekspertise dari tahun 1990-2006, lebih banyak pada jenis kelamin perempuan dibandingkan laki-laki yaitu 4:1. Menurut Livolsi dan Baloch $^{8}$ insidensi nodul tiroid yang ditemukan pada perempuan 4-10 kali lipat lebih tinggi dibandingkan laki-laki. Perbedaan jumlah tersebut menunjukkan efek dari kebiasaan dan gaya hidup, sebagai contoh diet rendah yodium. Perbedaan ini juga dapat disebabkan perbedaan biologis antara laki-laki dan perempuan.

Kasus nodul tiroid paling sering didapatkan pada kelompok usia 40-49 tahun dan 50-59 tahun masing-masing sebesar 27,5\%, diikuti dengan kelompok usia 30-39 tahun (15,6\%). Hasil penelitian ini selaras dengan pernyataan Livolsi dan Baloch $^{8}$ bahwa insidensi nodul tiroid meningkat pada orang dewasa dengan puncaknya pada kelompok usia 40-59 tahun. $^{8}$ Keadaan ini disebabkan oleh berkurangnya hormon tiroksin yang dihasilkan oleh kelenjar tiroid seiring bertambahnya usia, sehingga kelenjar tiroid harus bekerja ekstra dalam memroduksi hormon. Tingginya insidensi nodul tiroid menunjukkan kerentanan genetik dan paparan zat-zat karsinogen di lingkungan serta kurangnya asupan yodium. ${ }^{9}$ Gambaran USG paling sering ditemukan yaitu eggshell calcification yang menandakan bahwa nodul tiroid bersifat jinak. Hal ini 
disebabkan kebanyakan pasien yang ditemukan masih berusia aktif yaitu sekitar 4050 tahun. Hasil penelitian ini sejalan dengan penelitian Pasaribu di RS H. Adam Malik yang juga mendapatkan paling banyak nodul tiroid jinak. Eggshell calcification terbentuk akibat kurangnya asupan yodium sehingga terjadi kalsifikasi pada kelenjar tiroid akibat aktifitas kelenjar yang bertambah.

\section{SIMPULAN}

Berdasarkan hasil penelitian yang dilakukan di Bagian/SMF Radiologi RSUP Prof. R. D. Kandou Manado dapat disimpulkan bahwa kasus dengan nodul tiroid terbanyak pada jenis kelamin perempuan, kelompok usia 40-49 tahun dan 50-59 tahun, dengan nodul tiroid yang bersifat jinak dan gambaran ultrasonografi berupa eggshell calcification

\section{SARAN}

1. Klinis yang terdapat di lembar permintaan pemeriksaan USG perlu ditulis secara detail sehingga dapat dipertimbangkan diagnosis radiologik yang sesuai dengan pemeriksaan klinis.

2. Hasil ekspertise perlu diketik sesuai prosedur supaya dapat diarsipkan dengan baik dan jelas untuk kepentingan institusi yang bersangkutan.

3. Penulisan hasil ekspertise perlu memberikan informasi yang jelas dan detail, terutama dekripsi dari ukuran, letak. dan jumlah nodul.

4. Penelitian lanjut mengenai nodul tiroid sangat disarankan karena penelitian demikian masih sangat kurang dilakukan di Indonesia dan dapat dikorelasikan dengan hasil FNAB.

\section{DAFTAR PUSTAKA}

1. Djokomoeljanto R. Kelenjar tiroid, hipotiroidisme, dan hipertiroidisme. In: Sudoyo AW et al, editors. Buku Ajar Ilmu Penyakit Dalam Jilid III (5th ed). Jakarta: Penerbitan Ilmu Penyakit Dalam, 2009.

2. American Cancer Society. Thyroid cancer. [cited 2017 July 27]. Available from: http://www.cancer.org/cancer/thyroidc ancer/detailedguide/thyroid.

3. Welker MJ, Orlov D. 2013. Thyroid nodules. [cited 2017 July 27]. Available from: http://www/afserv @ aafp.org.

4. Brennan M, French J. Thyroid lumps and bumps. Australian Family Physician. 2007;36(7):

5. Lukitto P, Manoppo A, Azamris, et al. Protokol Penatalaksanaan Tumor/ Kanker Tiroid. Jakarta: Perhimpunan Ahli Bedah Onkologi Indonesia, 2003.

6. Kumar V, Abbas Ak, Fausto N. Robbins and Cortran Pathologic Basis of Disease. Philadelphia: Elsevier Saunders, 2013.

7. Pasaribu ET. Epidemiologi dan gambaran klinis kanker tiroid. Majalah Kedokteran Nusantara. 2006;39(3): 270-4.

8. Livolsi VA, Baloch ZW. Pathology of thyroid and parathyroid disease. In: Mills SE, Carter D, Reuter VE. Sternberg's Diagnostic Surgical Pathology (4th ed). Philadelphia: Elsevier, 2004; p. 493-527.

9. Hundahl S, Cady B, Cunningham MP. Initial result from a prospective study of 5583 cases of thyroid carcinoma treated in the United State during 1996. Cancer. 2000;89(1):134-9. 